Research article

\title{
INVESTIGATION ON THE ETIOLOGY OF SUBCLINICAL MASTITIS IN JERSEY AND HYBRID JERSEY DAIRY COWS
}

\author{
GÜRLER Hande ${ }^{*}$, FINDIK Arzu ${ }^{2}$, GÜLTIKKEN Nilgün ${ }^{1}$, AY Serhan Serhat ${ }^{1}$, \\ ÇIFTÇİ Alper ${ }^{2}$, KOLDAŞ Ece ${ }^{3}$, ARSLAN Serhat ${ }^{4}$, FINDIK Murat ${ }^{1}$
}

${ }^{1}$ Department of Obstetrics and Gynecology, Faculty of Veterinary Medicine, Ondokuz Mayıs University, Samsun-Turkey; ${ }^{2}$ Department of Microbiology, Faculty of Veterinary Medicine, Ondokuz Mayis University, Samsun-Turkey; ${ }^{3}$ Department of Obstetrics and Gynecology, Faculty of Veterinary Medicine, Mustafa Kemal University, Hatay-Turkey; ${ }^{4}$ Department of Biometry, Faculty of Veterinary Medicine, Ondokuz Mayıs University, Samsun-Turkey

(Received 10 $0^{\text {th }}$ December 2014; Accepted $8^{\text {th }}$ April 2015)

The aim of this study was to investigate the etiology of subclinical mastitis (SCM) in dairy Jersey cows with the use of bacteriological and molecular identification methods. In the study 121 Jersey and 78 hybrid Jersey cows with SCM were observed in the Samsun district of Turkey. A total of 411 California mastitis test (CMT) positive milk samples from these animals were examined bacteriologically. The prevalence of subclinical mastitis was $54.75 \%$ and $67.2 \%$ in Jerseys and hybrids, respectively. On bacteriological examination, a total of 92 strains were isolated from 411 milk samples. The most prevalent bacteria were Staphylococcus spp. (69.56\%). Among them 24 isolates were Staphylococcus aureus $(26.08 \%)$ the other isolates were Streptococcus dysgalactiae (23.91\%), Enterococcus spp. (3.26\%) and Streptococcus agalactiae (3.26\%). All strains were identified with bacteriological culture methods, as well as by Polymerase Chain Reaction (PCR). Gram-negative bacteria were not isolated. In conclusion, the etiology of SCM in full blood and hybrid Jersey dairy cows in Samsun and the prevalence of bacteria were determined. The relatively high prevalence of SCM indicates the potential need for the consideration of some factors contributing to the formation of mastitis (e.g. management) as well as bacterial agents. The present study and further studies may be useful to develop mastitis vaccines by means of providing true vaccine strain sources.

Key words: etiology, Jersey dairy cow, molecular identification, subclinical mastitis

\section{INTRODUCTION}

Subclinical mastitis still continues to be a major problem in dairy animals such as cattle, buffalo and ewes due to economic losses to dairy farms all over the world. These economic losses are caused by reduced milk yield, discarded milk, replacement cost, extra labor, costs of treatment, veterinary care and culling [1-6].

\footnotetext{
*Corresponding author: e-mail: hulusoy@omu.edu.tr, handeulusoy@gmail.com
} 
Subclinical mastitis is a disease that is difficult to detect due to the absence of any visible indications either in the milk or in the mammary glands. The diagnosis of SCM is based on the somatic cell count (SCC) and microbiological status of udder quarters [7]. CMT is an advantageous test due to its inexpensiveness and allows the detection of the number of somatic cells in the milk sample indirectly. In addition, it is the only cow-side test giving real-time results for selection of the quarters for subsequent bacteriological examination [8]. Bacteriological culture methods and biochemical tests are used to isolate and identify the bacteria causing SCM [9]. The primary causes of mastitis are bacteria, though it is also caused by non-bacterial pathogens such as viruses, fungi, yeasts, chlamydia and mycoplasmas [10]. Many species of bacteria have been determined as causative agents of mastitis in Turkey. Reported bacteria are Staphylococcus aureus, Staphylococcus epidermidis, Streptococcus agalactiae, Streptococcus dysgalactiae, Streptococcus uberis, Arcanobacterium pyogenes, Escherichia coli, Corynebacterium bovis, Pasteurella multocida, Bacillus subtilis, Bacillus cereus and Micrococcus spp. [11]. Identification of bacterial pathogens in the milk from cows with increased SCM is regarded as the definite diagnosis of mastitis and is important for epidemiological studies and disease control. Culture of milk samples from cows with increased SCM may yield no bacteria due to the presence of very low numbers of pathogens when samples are collected. Besides, antibiotic residues and leukocytes might be the cause of negative culture results [12]. Because of these limitations, molecular methods such as Polymerase Chain Reaction (PCR) have been used successfully for the identification of various mastitis pathogens. Furthermore, PCR is a rapid method with high sensitivity and specificity which detects bacteria even in the presence of residual antimicrobials or preservatives in the milk [13-16].

The aim of this study was to determine the etiology of subclinical mastitis (SCM) in Jersey dairy cows using bacteriological and PCR methods as well as to investigate the sensitivity of the isolated bacteria to antimicrobial drugs.

\section{MATERIALS AND METHODS}

A total of 337 dairy cattle (221 Jersey and 116 Jersey hybrid) at 25 family and agricultural type farms were investigated from March 2011 to February 2012. Among these cattle 199 (121 Jersey and 78 hybrid Jersey) were diagnosed SCM. California mastitis test positive milk samples (225 and 186 were from Jersey and hybrid Jersey cows, respectively) were examined bacteriologically. Afterwards, suspicious colonies were identified morphologically, microscopically and biochemically. Ethical approval was obtained from the Animal Ethics Committee, University of Ondokuz Mayis, Samsun, Turkey (Approval Nr. 201001).

\section{California mastitis test and milk sample collection}

California mastitis test was used in order to detect the presence of SCM in the field. The procedures and interpretations were performed by traditional methods [17]. Teat 
ends were disinfected with cotton swabs with $70 \%$ alcohol, allowed to dry and the foremilks from quarters were discarded. CMT was performed and approximately 15 $\mathrm{ml}$ milk samples of positive quarters were collected in sterile tubes and immediately transported under cold conditions to the laboratory.

\section{Isolation and Identification of Microorganisms}

After CMT positive samples were brought to the laboratory, they were homogenized with a vortex mixer; each of them was plated on blood agar enriched with $5 \%$ sheep blood and McConcey agar plates. The plates were incubated at $37^{\circ} \mathrm{C}$ for $24-48$ hours. Then, suspicious colonies were evaluated for cultural characteristics (haemolysis, pigmentation), microscopy (Gram staining) and biochemical characteristics (catalase, oxidase, coagulase, aesculin hydrolysis, CAMP tests) [18].

\section{Antibiotic susceptibility test}

Antibiotic susceptibilities of the strains isolated from the samples in the study were determined by Kirby-Bauer Disc Diffusion Method according to the National Committee for Clinical Laboratory Standards (NCCLS) (2003) [19]. The antibiotic discs were penicillin $\mathrm{G}(10 \mathrm{U})$, vancomycin $(30 \mu \mathrm{g})$, ampicillin-dicloxacillin $(10 \mathrm{k} \mu \mathrm{g} / 1 \mu \mathrm{g})$, amoxicillin-clavulonic acid $(20 \mu \mathrm{g} / 10 \mu \mathrm{g})$, teicoplanin $(30 \mu \mathrm{g})$, neomycin $(10 \mu \mathrm{g})$, enrofloxacin $(5 \mu \mathrm{g})$, oxytetracycline $(30 \mu \mathrm{g})$, spiramycin $(100 \mu \mathrm{g})$, rifaximin $(40 \mu \mathrm{g})$, rifaximin-cefacetrile $(40 \mu \mathrm{g} / 30 \mu \mathrm{g})$ and cefaperazone $(75 \mu \mathrm{g})$. The results were recorded as susceptible $(\mathrm{S})$ or resistant $(\mathrm{R})$.

\section{DNA extraction}

DNA for direct PCR was extracted by boiling the intact bacteria. A tissue extraction kit $\left(\right.$ Invitrogen ${ }^{\circledR}$ ) was used for PCR application on milk samples according to the manufacturer's instructions.

\section{Polymerase Chain Reaction (PCR)}

PCR protocols were used for bacteria commonly isolated from SCM. To identify Staphylococcus spp. by PCR a method by Ciftci et al. [16] was used. Briefly, $5 \mu$ l of extracted DNA was added to $25 \mu \mathrm{l}$ of PCR mixture. This PCR mixture consisted of 1XPCR buffer (50 mm KCl, $20 \mathrm{mM}$ Tris $\mathrm{HCl}$ ), $5 \mu$ l of $25 \mathrm{mM} \mathrm{MgCl}_{2}, 3 \mu$ l of $10 \mathrm{mM}$ deoxynucleotide triphosphat (dNTP) mixture, $1 \mu$ l of $20 \mu \mathrm{M}$ 16S rRNA (Staphylococcus spp. specific) primers and 2U Taq DNA polymerase. Amplification conditions were as follows: Initial denaturation at $94^{\circ} \mathrm{C}$ for $52 \mathrm{~min}$, followed by 30 cycles of $45 \mathrm{~s}$ at $94^{\circ} \mathrm{C}, 45 \mathrm{~s}$ at $68^{\circ} \mathrm{C}, 90 \mathrm{~s}$ at $72^{\circ} \mathrm{C}$ and final extention at $72^{\circ} \mathrm{C}$ for $10 \mathrm{~min}$ amplicons were loaded onto $1.5 \%$ agarose gel containing $1 \mu \mathrm{g} / \mathrm{ml}$ etidium bromide and amplified DNA fragments were separated by agarose gel electrophoresis. Bands were visualized under UV transilluminator. Identification of $S$. aureus strains by PCR was performed using a method by Kuzma et al. [13]. Briefly, the total reaction volume was $50 \mu \mathrm{l}$ 
and PCR mixture contained $1.5 \mathrm{mM} \mathrm{MgCl}, 10 \mathrm{mM}$ Tris- $\mathrm{HCl}(\mathrm{pH} 9.0), 50 \mathrm{mM} \mathrm{KCl}$, $0.1 \%$ Triton ${ }^{\circledR} \mathrm{X}-100,200 \mathrm{mM}$ (each) deoxynucleotide triphosphat, $0.2 \mathrm{mM}$ of primers (Table 1) and $0.625 \mathrm{U}$ Taq polymerase. Amplification conditions were as follows: initial denaturation at $95^{\circ} \mathrm{C}$ for $10 \mathrm{~min}, 37$ cycles of denaturation at $94^{\circ} \mathrm{C}$ for $1 \mathrm{~s}$, annealing at $55^{\circ} \mathrm{C}$ for $30 \mathrm{~s}$, elongation at $72^{\circ} \mathrm{C} 1.5 \mathrm{~min}$ and final elongation at $72^{\circ} \mathrm{C} 5 \mathrm{~min}$ PCR products were separated and visualized as above. A PCR protocol by Abd El-Razik et al. [12] was used to identify $S$. dysgalactiae and $S$. agalactiae strains. All reactions were carried out in a $50 \mu \mathrm{l}$ volume. Two hundred microliter of extracted DNA, $5 \mu \mathrm{M}$ primer (Table 1) and $25 \mu$ l of Taq PCR Master Mix (Taq PCR Master Mix Kit, Cat no 201443, Qiagen $^{\mathbb{R}}$ ) were brought together in this volume.

Table 1. Primers used for identification of the isolates from cases of SCM by PCR

\begin{tabular}{|c|c|c|c|c|}
\hline Target & Primer & Sequence (5'-3') & $\begin{array}{c}\text { PCR } \\
\text { product } \\
\text { (bp) }\end{array}$ & Source \\
\hline \multirow[t]{2}{*}{ Staphylococcus spp. } & 16SrRNA & АACTCTGTTATTAGGGAAGAACA & \multirow[t]{2}{*}{756} & \multirow{2}{*}{$\begin{array}{l}\text { Ciftci } \\
\text { et al. (2009) }\end{array}$} \\
\hline & 16SrRNA & ССАССТTCCTCCGGTTTGTCACC & & \\
\hline \multirow[t]{2}{*}{ S. aureus } & Sau327 & GGACGACATTAGACGATCA & \multirow[t]{2}{*}{1318} & \multirow{2}{*}{$\begin{array}{l}\text { Abd El-Razik } \\
\text { et al. (2010) }\end{array}$} \\
\hline & Sau1645 & CGGGCACCTATTTTCTATCT & & \\
\hline \multirow[t]{2}{*}{ S. dysgalactiae } & Sdy105 & AAAGGTGCAACTGCATCACTA & \multirow[t]{2}{*}{281} & \multirow{2}{*}{$\begin{array}{l}\text { Abd El-Razik } \\
\text { et al. (2010) }\end{array}$} \\
\hline & Sdy386 & GTCACATGGTGGATTTTCCA & & \\
\hline \multirow[t]{2}{*}{ S. agalactiae } & Sag40 & CGCTGAGGTTTGGTGTTTACA & \multirow[t]{2}{*}{405} & \multirow{2}{*}{$\begin{array}{l}\text { Abd El-Razik } \\
\text { et al. (2010) }\end{array}$} \\
\hline & Sag445 & САСТССТАССААСGTTCTTC & & \\
\hline \multirow[t]{2}{*}{ S. uberis } & STRU-UbI & TAAGGAAGACGTTGGTTAAG & \multirow[t]{2}{*}{330} & \multirow{2}{*}{$\begin{array}{l}\text { Moatamedi } \\
\text { et al. (2007) }\end{array}$} \\
\hline & STRU-UbII & TCCAGTCCTTAGACCTTCT & & \\
\hline \multirow[t]{2}{*}{ Enterococcus spp. } & Ent1 & TACTGACAAACCATTCATGATG & \multirow[t]{2}{*}{112} & \multirow{2}{*}{$\begin{array}{l}\text { Ke et al. } \\
(1999)\end{array}$} \\
\hline & Ent2 & AACTTCGTCACCAACGCGAAC & & \\
\hline \multirow[t]{2}{*}{ E. Coli } & Eco2083 & GCTTGACACTGAACATTGAG & \multirow[t]{2}{*}{662} & \multirow{2}{*}{$\begin{array}{l}\text { Abd El-Razik } \\
\text { et al. (2010) }\end{array}$} \\
\hline & Eco2745 & GCACTTATCTCTTCCGCATT & & \\
\hline
\end{tabular}

Amplification conditions were as follows: initial denaturation at $95^{\circ} \mathrm{C}$ for $2 \mathrm{~min}, 35$ cycles of denaturation at $94^{\circ} \mathrm{C}$ for $45 \mathrm{~s}$, annealing at $57^{\circ} \mathrm{C}$ and $60^{\circ} \mathrm{C}$ for $45 \mathrm{~s}$ for S. dysgalactiae and S. agalactiae primers, respectively, elongation at $72^{\circ} \mathrm{C}$ for $45 \mathrm{~s}$ and final extention at $72^{\circ} \mathrm{C}$ for $10 \mathrm{~min}$. Amplification products were evaluated as above. The PCR protocol by Moatamedi et. al. [14] was used to identify S. uberis. Briefly, in a $50 \mu \mathrm{l}$ volume, $5 \mu \mathrm{l}$ of extracted DNA, $2.5 \mathrm{U}$ Taq polymerase, $0.4 \mathrm{mM}$ of each deoxynucleotide triphosphate, $50 \mathrm{pmol}$ of each primer, $5 \mu$ l of 10xPCR buffer $(500$ $\mathrm{mM} \mathrm{KCl}, 200 \mathrm{mM}$ tris- $\mathrm{HCl}, \mathrm{pH} 8.4), \mathrm{MgCl}_{2}$ with optimal concentration were brought together. Amplification conditions were as follows: first denaturation at $94^{\circ} \mathrm{C}$ for $2 \mathrm{~min}$, 40 cycles of $94^{\circ} \mathrm{C}$ for $30 \mathrm{~s}, 55^{\circ} \mathrm{C}$ for $30 \mathrm{~s}, 72^{\circ} \mathrm{C}$ for $30 \mathrm{~s}$ and final extention at $72^{\circ} \mathrm{C}$ for 
7 min. PCR products were evaluated as above. For identification of Enterococcus spp. by PCR, a protocol by Ke et al. [20,21] was used. Briefly, $1 \mathrm{ng}$ of extracted DNA was added to $19 \mu$ of PCR mixture $\left(50 \mathrm{mM} \mathrm{KCl}, 10 \mathrm{mM}\right.$ Tris- $\mathrm{HCl}$ (pH 9.0), 0.1\% Triton ${ }^{\circledR} \mathrm{X}-100$, $2.5 \mathrm{mM} \mathrm{MgCl}_{2}, 0.2 \mathrm{mM}$ of each Enterococcus-specific primers (Ent1 and Ent2; Table 1), $200 \mathrm{mM}$ of each deoxynucleotide triphosphate $\left(\right.$ Pharmacia Biotech $\left.^{\circledR}\right), 3.3 \mu \mathrm{g} / \mathrm{ml}$ of bovine serum albumin (BSA) (Sigma-Aldrich Canada Ltd., Oakville, Ontario, Canada), $0.5 \mathrm{U}$ of Taq polymerase (Promega ${ }^{\circledR}$ ). Amplification conditions were as follows: first denaturation at $95^{\circ} \mathrm{C}$ for $3 \mathrm{~min}, 35$ cycles of $95^{\circ} \mathrm{C}$ for $30 \mathrm{~s}, 55^{\circ} \mathrm{C}$ for $30 \mathrm{~s}, 72^{\circ} \mathrm{C}$ for $1 \mathrm{~min}$ and final extention at $72^{\circ} \mathrm{C}$ for $7 \mathrm{~min}$. PCR products were evaluated as above.

\section{Statistics}

Data were evaluated with SAS (2009) statistics suited to summarize means, frequencies and standard error of means.

\section{RESULTS}

\section{Cultural Identification}

Of the 411 milk samples, a total of 92 strains were isolated. Of sixty-four strains $(69.56 \%)$ identified as Staphylococcus spp., 24 strains $(26.08 \%)$ were identified as $S$. aureus according to their colony morphology (hemolysis, pigment production) and biochemical reactions (coagulase, DNase, mannitol fermentation). Of 92 strains, 25 were $(27.17 \%)$ Streptococcus spp. and three of them $(3.26 \%)$ were S. agalactiae and 22 $(23.91 \%)$ were $S$. dysgalactiae. Three of all the isolates were identified as Enterococcus spp. $(3.26 \%)$. S. uberis was not isolated. Isolated bacterial strains and their percentages are given in Table 2.

Table 2. Distribution of the isolates identified by cultural methods and PCR

\begin{tabular}{lccc}
\hline \multirow{2}{*}{ Bacteria } & Cultural identification & PCR from culture & * PCR from milk \\
\cline { 2 - 4 } & No (\%) & No (\%) & No (\%) \\
\hline S. aureus & $24(26.08)$ & $24(26.08)$ & $24(5.83)$ \\
$\begin{array}{l}\text { Staphylococcus spp. other } \\
\text { than S. aureus }\end{array}$ & $40(43.47)$ & $40(43.47)$ & $40(9.73)$ \\
S. agalactiae & $3(3.26)$ & $3(3.26)$ & $3(0.72)$ \\
S. dysgalactiae & $22(23.91)$ & $22(23.91)$ & $22(5.35)$ \\
S. uberis & $0(0)$ & $0(0)$ & $0(0)$ \\
Enterococcus spp. & $3(3.26)$ & $3(3.26)$ & $3(0.72)$ \\
\hline
\end{tabular}

*PCR analysis results from 411 milk samples

\section{Antibiotic Susceptibility Test}

While all $S$. aureus and other Staphylococcus spp. strains were susceptible to rifaximin, rifaximin + cefacetrile, they showed resistance against spiramycin. These strains showed 


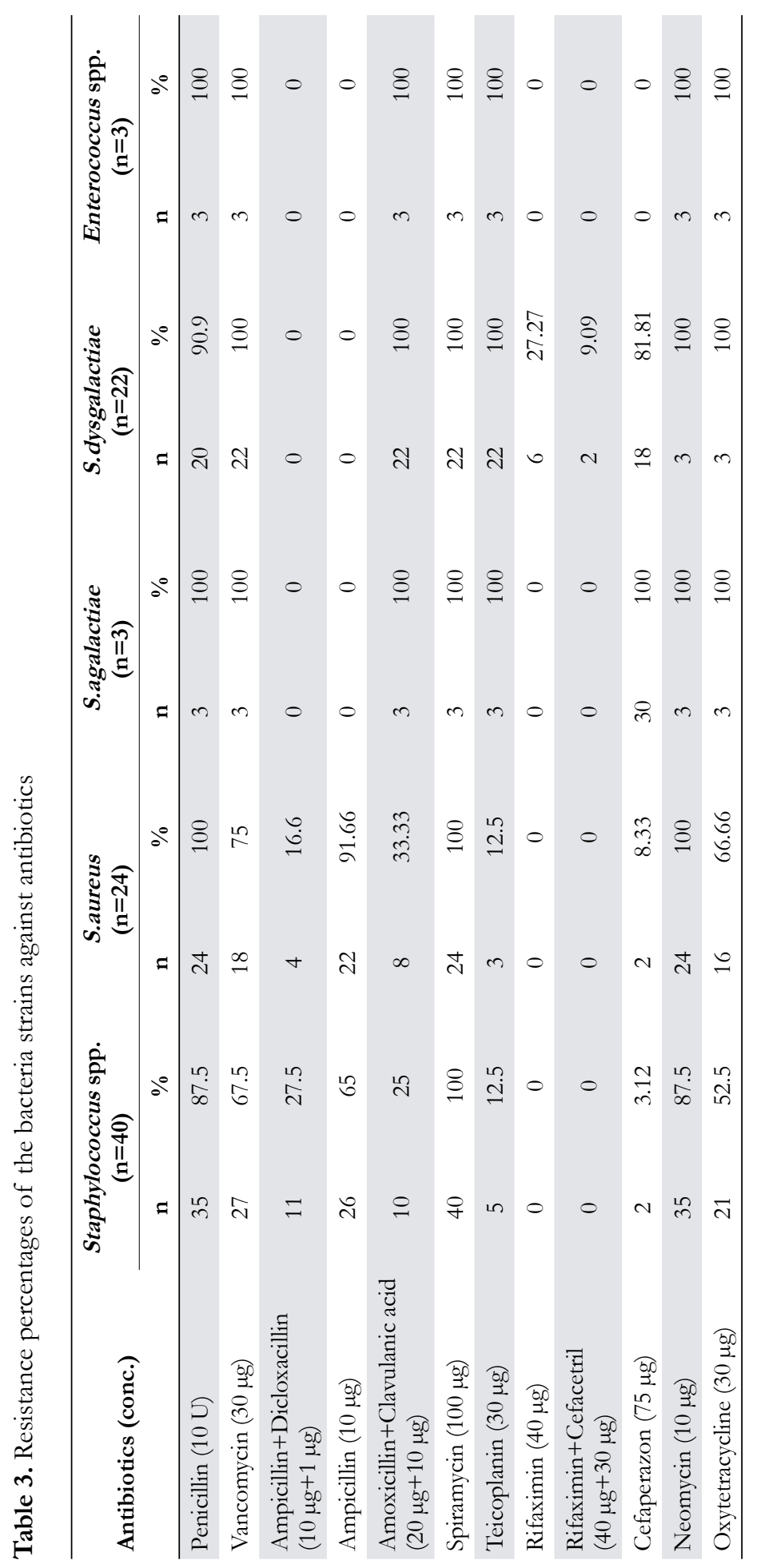


a variety of resistance against other antibiotics. Namely, $>50 \%$ of the Staphylococcus spp. strains (other than $S$. aureus) showed resistance to penicillin (87.5\%), neomycin $(87.5 \%)$, vancomycin $(67.5 \%)$, ampicillin $(65 \%)$ and oxytetracycline $(52.5 \%)$. While all $S$. aureus strains were resistant to spiramycin, penicillin and neomycin, $91.66 \%$ of them showed resistance to ampicillin. Besides, $S$. aureus strains showed relatively high resistance to vancomycin $(75 \%)$ and oxytetracycline (66.6\%). S. aureus and other Staphylococcus spp. strains showed lower resistance to ampicillin+dicloxacillin, amoxicillin+clavulanic acid, teicoplanin and cefaperazone. The resistance percentages of the strains to 12 antibiotics are given in Table 3. All S. agalactiae, S. dysgalactiae and Enterococcus spp. strains were resistant to vancomycin, amoxicillin+clavulanic acid, spiramycin, teicoplanin, neomycin and oxytetracycline. In addition, all of these strains were susceptiple to ampicillin and ampicillin+dicloxacillin. Penicillin resistance occurred in all S. agalactiae and Enterococcus spp. strains. Other resistance percentages are given in Table 3.

\section{Molecular Identification}

In Table 2, PCR results from both culture and milk (directly) are given. All strains identified by cultural methods were further identified by PCR protocols from culture. After PCR protocols from direct milk samples collected from respective quarters, the same bacterial strains identified both by cultural and culture-PCR methods were identified again. No Gram negative bacteria (including E. coli) was found in milk samples neither by cultural nor by molecular methods.

\section{DISCUSSION}

Subclinical mastitis is a major problem since it does not present clinical symptoms in dairy cows. The lack of visible symptoms makes it difficult to recognize the infection in udders and long-term effects which occur during the undetected period. Causative organisms might lead to considerable economic losses because of decreased milk production and altered milk composition [14]. In order to treat mastitis effectively and create prevention strategies etiological agents must be determined. Treatment of mastitis relies heavily on the use of antibiotics as the cause is mostly bacterial [4].

The present study was conducted to determine the etiology of subclinical mastitis with bacteriological and molecular methods in Jersey and hybrids, as well as antibiotic resistance of causative bacteria. Mastitis is a multifactorial disease for which more than 250 microbial species, subspecies and serotypes have been isolated and identified as causative agents [5]. These agents are grouped in three categories as contagious, environmental and the others. Many studies have been performed concerning subclinical mastitis in the world and $S$. aureus was reported to be the most important contagious microorganism in cattle [5, 12-14]. Similarly, the studies conducted in Turkey revealed that $S$. aureus was the most common agent [22-25]. The ratio from the previous studies performed at different geographic regions in Turkey was $28.3 \%$ in the eastern Anatolia region [22], 39.04\% in Elazığ [26], 24.63\% in the southeast Anatolia 
region [24], 32.5\% in Şanliurfa [27], 28.7\% in the central Anatolia region [23]. In the present study performed in the Black sea region of Anatolia, similar ratio of $S$. aureus was detected $(26.08 \%)$. In a study from Marmara region [24] S. aureus isolation rate was found quite lower $(4.44 \%)$ than in the other regions of Anatolia. Since management is very important in mastitis prevention; diversity of housing conditions is thought to be effective in the etiology of mastitis.

$S$. agalactiae is reported to be highly contagious and one of the important causes of subclinical infections. It is an obligate bacteria in the bovine mammary gland that can be transmitted to healthy cows via poor milking hygiene $[14,28]$. In some studies, the presence of $S$. agalactiae was detected to be between $6.16-10.7 \%[24,26,28]$. In the present study the ratio $(3,26 \%)$ was determined to be lower than the other studies.

Among Streptococcus species, S. uberis and $S$. dysgalactiae were important species as environmental agents [25]. The most important source of environmental organisms is bedding material. It was reported that moisture in the environment should be decreased to control the environmental microrganisms. Accordingly, clean pastures and environment, dry milking equipment and pre-dipping hygiene are important factors to reduce the exposure of these organisms [5]. Acar et al. [25] have reported that $17(28.81 \%)$ Streptococcus spp. were isolated from 59 SCM positive milk samples (1 S.agalactiae, 8 S.dysgalactiae, 2 S.uberis, 6 S.fecalis). Similarly, Tel et al. [27] have also reported that $16(6.2 \%)$ Streptococcus spp. isolation was performed from 258 SCM positive milk samples. In the present study, 25 (27.17\%) were isolated from 92 bacteria strain (3 S.agalactiae, 22 S.dysgalactiae). S. uberis was not isolated.

E. coli is an environmental mastitis agent similar to $S$. uberis and $S$. dysgalactiae [5, 22, 24]. Although in the present study E. coli was not isolated, in the studies carried out in Kars [22], Şanlıurfa [27], Diyarbakır [24], Elazı̆̆ [26] E.coli was determined as 5.9\%, $6.2 \%, 8.58 \%, 8.9 \%$, respectively. However, in the study carried out in Kirikkale [23] the presence of E.coli was determined to be very low $(0.94 \%$.)

Enterococci are the natural flora agent of the gastrointestinal system in humans and animals and reported to be isolated in the dry period [19, 29]. Its ratio might be $6-42 \%$ in mastitis cases [28]. In our study it was 3.6\%.

Antimicrobial agents are the most frequently used therapeutics for subclinical mastitis cases. A prudent antibiotic therapy improves udder health, decreases the risk of exacerbating clinical mastitis and prevents economic losses. An important factor affecting the success of antibiotic therapy is the resistance of the agents to antibiotics. In several studies, many differences in the resistance against antibiotics by the strains isolated from subclinical mastitis and different geographical regions have been demonstrated [23, 24, 27, 28, 30, 31]. In our study, resistance of all strains against twelve antimicrobials was tested. All $S$. aureus, $S$. agalactia and Enterococcus spp. and also most of other Staphylococcus spp. (87.5\%) and S. dysgalactiae (90.9\%) were resistant to penicillin. All Streptococcus and Enterococcus strains were found resistant against vancomycin, amoxicillin+clavulanic acid, spiramycin, teicoplanin, neomycin 
and oxytetracycline. In many reports [23, 24, 27, 30, 31] most of the Streptococcus strains, even all of them isolated from bovine subclinical mastitis cases were reported to be sensitive to penicillin. S. agalactiae, a group B Streptococcus (GBS) was not reported to be resistant to penicillin so far. However, a few reports are available for GBS clinical strains with reduced sensitivity to penicillin [33, 34]. Moreover, in recent times 60 and $100 \%$ of resistance to penicillin have been reported in Streptococcus spp. strains isolated from subclinical bovine mastitis by Ikiz et al. [24] and Yeşilmen et al. [28], respectively. Although all $S$. agalactiae (3 strains) and $90.9 \%$ of $S$. dysgalactiae strains were found to be penicillin resistant, it should be considered that streptococci isolated in our study were few in number. Nevertheless, this resistance should not be ignored. Usually intramammary infusion is the most commonly recommended route to treat mastitis cases and one of the antibiotics that has a good distribution into the mammary gland for mastitis treatment is spiramycin $[35,36]$. In many studies $[23,25$, 37], strains isolated from subclinical mastitis including Streptococcus spp., Staphylococcus spp. and Enterococcus spp. have been found to be sensitive to spiramycin. However, in our study all strains were resistant to spiramycin. While Malinowski et al. [30] have reported that the neomycin resistance rates of $S$. agalactiae and $S$. aureus strains were $80 \%$ and $22.7 \%$, respectively; low sensitivity to neomycin both to $S$. aureus $(8.33 \%)$ and $S$. agalactiae (4\%) has been reported by Ikiz et al. [28]. In our study, all Streptococcus spp, Enterococcus spp. and S. aureus strains and most of the other Staphylococci $(87.5 \%)$ were resistant to neomycin. Similarly, all Streptococcus spp., Enterococcus spp. and most of S. aureus $(75 \%)$ and other Staphylococci $(67.5 \%)$ were resistant to vancomycin. These findings were compatible with the findings reported by Ikiz et al. [28] indicating that the percentage of susceptibility of $S$. aureus and $S$. agalactiae to vancomycin was $8.33 \%$ and $8 \%$, respectively. Generally in many studies, $[23,25,28,30,38]$ it has been reported that Streptococus spp. and Staphylococcus spp. isolates were sensitive to amoxicillin and/or amoxicillin clavulanic acid. We found that all Streptococci and Enterococci were resistant against amoxicillin clavulanic acid but only $33.33 \%$ of $S$. aureus and $25 \%$ of other staphylococci were resistant to this antibiotic combination. In contrast to our findings, Yeşilmen et al. [24] have reported that all Streptococci were sensitive and all S. aureus isolates were resistant to amoxicillin clavulanic acid. Susceptibility of Staphylococci, Streptococci and Enterococci to tetracycline/oxytetracycline has been evaluated in many studies and although some researchers [23, 27, 38, 39] have found that the strains isolated from subclinical mastitis in different regions showed varying percentages of sensitivity to tetracycline, in some studies $[24,25,28,30]$ the sensitivity of the strains to tetracycline/oxytetracycline has been showed to be relatively low and even resistant. Ikiz et al. [28] determined only $16 \%$ and $16.6 \%$ sensitivity of S. agalactiae and S. aureus to oxytetracycline, respectively. Acar et al. [25] have reported low sensitivity $(35.3 \%)$ of their isolates to oxytetracycline. Malinowski et al. [30] reported more than $40 \%$ resistance to tetracycline in $S$. agalactiae (40.2\%), other streptococci $(62.3 \%)$ and $S$. aureus $(41.7 \%)$. In our study all Streptococci and Enterococci and most of $S$. aureus $(66.66 \%)$ and other Stapyblococci $(52.5 \%)$ were resistant to oxytetracycline. These findings were compatible with the results of the studies mentioned above. 
The prominent antibiotic and antibiotic combination, to which most bacterial strains were susceptible, were rifaximin and rifaximin+cefacetrile combination. While all staphylococci were detected to be sensitive to these antibiotics, only $6(27.27 \%)$ and $2(9.09 \%) S$. dysgalactiae strains were resistant to rifaximine and rifaximin + cefacetrile combination, respectively. Rifaximin resistance is known to be rare despite concerns about rifaximin resistance of some bacteria (e.g. Staphylococcus spp.) in vivo have been raised [40, 41]. On the other hand, it has been reported that the development of bacterial resistance to rifaximin appears to occur with a low frequency in vitro [41]. Several studies evaluated the resistance of mastitis pathogens against rifaximin in vitro. Malinowski et al. [30] reported that the resistance of $S$. agalactiae and other streptococci against rifaximin were $17.6 \%$ and $25.8 \%$ respectively and for coagulase negative staphylococci the percentage of rifaximin resistance was only $2.9 \%$. Idriss et al. [42] reported that the percentage of rifaximin resistance of $S$. aureus and $S$. agalactiae were $5.26 \%$ and $50 \%$, respectively.

Consequently, the present study revealed that the ratio of contagious ( $S$. aureus, $S$. agalactiae) and environmental ( $S$. dysgalactiae, S.uberis, Enterococcus spp.) agents were $29.34 \%$ and $70.66 \%$, respectively. High proportions of environmental agents indicate the importance of milking hygiene and dry cow therapy. On the other hand antibiotic susceptibility of mastitis pathogens to antibiotics was variable. In order to achieve the desired effect of antibiotic treatment, the susceptibility status of the strains isolated from mastitis cases in Samsun region should be considered.

\section{Acknowledgements}

This study was supported by University of Ondokuz Mayıs (Project Id: PYO. VET.1901.10.005). We also would like to thank to TIGGEM Samsun, Karaköy Agricultural Enterprises for its support.

\section{REFERENCES}

1. Bradley AJ: Bovine mastitis: An evolving disease. Vet J, 164, 117-126, 2002.

2. Ergun Y, Aslantas O, Kirecci E, Sarbay MK, Ates AT, Ulku A, Demir C: Prevalence and etiology of subclinical mastitis in Awassi dairy ewes in southern Turkey. Turk J Vet Anim Sci, 33, 477-483, 2009.

3. Ozenc E, Vural MR, Seker E, Ucar M: An evaluation of subclinical mastitis during lactation in Anatolian buffaloes. Turk J Vet Anim Sci, 32, 359-368, 2008.

4. Pellegrino M, Giraudo J, Raspanti C, Odierno L, Bogni C: Efficacy of immunization against bovine mastitis using Staphylococcus aureus avirulent mutant vaccine. Vaccine, 28, 45234528, 2010.

5. Sudhan NA, Sharma N: Mastitis-An important production disease of dairy animals. SMVS' DAIRY YEAR BOOK, 72-88, 2010.

6. Trajčev M, Nakov D, Hristov S, Andonov S I, Joksimović-Todorović Mirjana: clinical mastitis in Macedonian dairy herds. Acta Vet-Beograd, 63, 63-76, 2013. 
7. Makovický P, Makovický P, Nagy M, Rimárová K, Diabelková J: Genetic parameters for somatic cell count, logscc and somatic cell score of breeds: Improved valachian, tsigai, lacaune and their crosses. Acta Vet-Beograd, 64, 386-396, 2014.

8. Pyorala S: Indicators of inflammation in diagnosis of mastitis. Vet Res, 34, 565-578, 2003.

9. Viguer C, Arora A, Gilmarti N, Welbeck K, O’Kennedy R: Mastitis detection: current trends and future perspectives. Tib Tech, 27, 486-493, 2009.

10. Wellenberg GJ, van der Poel WHM, Van Oirschot JT: Viral infections and bovine mastitis: A review. Vet Microbiol, 88, 27-45, 2002.

11. Turkyılmaz S, Yıldız O, Oryasin E, Kaynarca S, Bozdogan B: Molecular identification of bacteria isolated from dairy herds with mastitis. Kafkas Univ Vet Fak Derg, 16, 1025-1032, 2010.

12. Abd El-Razik KA, Abdelrahman KA, Ahmed YF, Gomaa AM, Eldebaky HA: Direct identification of major pathogens of the bubaline subclinical mastitis in Egypt using PCR. J Am Sci, 10, 652-660, 2010.

13. Kuzma K, Malinowski E, Lassa H, Kłossowska A: Specific detection of Staphylococcus aureus by PCR in intramammary infection. B Vet I Pulawy, 47, 183-190, 2003.

14. Moatamedi H, Seyfiabad Shapouri M, Chorbanpoor M, Jamshidian M, Gooraninejad SA: Polymerase chain reaction based study on the SCM caused by S. agalactiae, S. dysgalactiae and S. uberis in cattle in Ahvaz. IJVR, 8, 260-265, 2007.

15. Rajić Savić N, Katić V, Velebit B: Characteristics of coagulase positive staphylococci isolated from milk in cases of subclinical mastitis. Acta Vet-Beograd, 64, 115-123, 2014.

16. Cengiz S, Dinç G, Söğüt MÜ: Detection of several virulence properties, antibiotic resistance and phylogenetic relationship in E. coli isolates originated from cow mastitis. Acta VetBeograd, 64 , 413-425, 2014.

17. Bastan A: İneklerde Meme Sağllğı ve Sorunları. 124, Kardelen Ofset, Ankara, 2010.

18. Quinn PJ, Carter ME, Markey BK, Carter GR: Clinical Veterinary Microbiology. MosbyYear Book Europe, London, 1994.

19. National Committee for Clinical laboratory Standards: Performance standards for antimicrobial susceptibility testing; fourteenth informational supplement: M2-A8 performance standards for antimicrobial disk susceptibility test; approved Standard. 8thed. National Committee for Laboratory Standards, Wayne, PA, 2003.

20. Ciftci A, Findik A, Onuk EE, Savasan S: Detection of methicillin resistance and slime factor production of Staphylococcus aureus in bovine mastitis. Braz J Microbiol, 40, 254261, 2009.

21. Ke D, Picard FJ, Martineau F, Me'nard C, Roy PH, Ouellette M, Bergeron MGÇ: Development of a PCR assay for rapid detection of Enterococci. J Clin Microbiol, 37, 3497-3503, 1999.

22. Sevinti DA, Sahin M: Determining of B-lactamase activity and resistance against some antibiotics of Staphylococcus strains isolated from bovine mastitis. Vet Bil Derg, 25, 23-28, 2009.

23. Macun HC, Yagc1 IP, Unal N, Kalender H, Sakarya F, Yildirim M: Agent isolation and antibiotic resistance in dairy cows with subclinical mastitis in Kırıkkale. J Fac Vet Med Univ Erciyes, 8(2): 83-89, 2011.

24. Yesilmen S, Ozyurtlu N, Bademkıran S: The isolation of subclinical mastitis agents and determination of the sensitive antibiotics in dairy cows in Diyarbakir province. Dicle Univ Vet Fak Derg, 1, 24-29, 2012. 
25. Acar G, Yilmaz E, Solmaz H, Cantekin Z: The isolation of streptococcal agents from cattle with subclinical mastitis in Hatay region and detection of their susceptibilities against some antibiotics. AVKAE Derg, 2, 1-5, 2012.

26. Gulcu HB, Ertas HB: Elazığ yöresinde mezbahada kesilen ineklerde mastitisli meme loblarınınn bakteriyolojik incelenmesi. Turk J Vet Anim Sci, 28, 91-94, 2004.

27. Tel OY, Keskin O, Zonturlu AK, Arserim Kaya NB: Şanlıurfa yöresinde subklinik mastitislerin görülme oranı, aerobik bakteri izolasyonu ve duyarlı antibiyotiklerin belirlenmesi. FU SBVD, 23, 101-106, 2009.

28. Ikiz S, Basaran B, Bingol EB, Cetin O, Kasikci G, Ozgur NY, Ucmak M, Yilmaz O, Gunduz MC, Sabuncu A: Presence and antibiotic susceptibility patterns of contagious mastitis agents (Staphylococcus aureus and Streptococcus agalactiae) isolated from milks of dairy cows with subclinical mastitis, Turk J Vet Anim Sci, 37, 569-574, 2013.

29. Cengiz S, Tekin O, Akan M: Molecular typing of Enterococcus spp. isolated from cow mastitis, Vet J Ankara Univ, 58, 17-20, 2011.

30. Malinowski E, Lassa H, Smulski S, Klossowka A,Kaczmarowski M: Antimicrobial susceptibility of bacteria isolated from cows with mastitis in 2006-2007, Bull Vet Inst Pulawy, 52, 565-572, 2008.

31. Persson Y, Nyman AKJ, Grönlund-Andersson U: Etiology and antimicrobial susceptibility of udder pathogens from cases of subclinical mastitis in dairy cows in Sweden. Acta Vet Scand, 53(1): 36, 2011.

32. El-Jakee J, Hableel HS, Kandil M, Hassan OF, Khairy EA, Marouf SA: Antibiotic resistance patterns of isolated from mastitic cows and ewes in Egypt, Global Vet, 10, 264-270, 2013.

33. Lopardo H: Antimicrobial resistance in $\beta$-hemolytic streptococci in Argentina. In, MéndezVilas (Ed): Communicating Research and Educational Topics and Trends in Applied Microbiology, 794-798, 2007.

34. Jain B, Tewari A, Bhandari BB, Jhala MK: Antibiotic resistance and virulence genes in Streptococcus agalactiae isolated from cases of bovine subclinical mastitis. Vet Arhiv, 82, 423-432, 2012.

35. Pyorala S: Treatment of mastitis during lactation. Ir Vet J, 62(4): 40, 2009.

36. Du Preez JH: Bovine mastitis therapy and why it fails. JSAVA, 71, 201-208, 2000.

37. Bakir M, Sabrina R, Toufik M: Antibacterial susceptibility profiles of subclinical mastitis pathogens isolated in Batna and Setif governorates (east of Algeria), Vet World, 4, 537-541, 2011.

38. Bulla TR, Rana YS, Sharma A: Comparison of different routes of administration of antibiotic therapy for sub-clinical mastitis in buffaloes. Haryana Vet, 44, 86-87, 2005.

39. Ekin IH, Gurturk K: İneklerde subklinik mastitis olgularından izole edilen streptokokların serogruplandırılması ve çeşitli biyokimyasal özellikleri üzerine araştırmalar, YYU Sag Bil Ens Derg, 4, 21-27, 1998.

40. Kim M, Morales W, Hani AA, Kim S, Kim G, Weitsman S, Chang C, Pimentel M: The effect of rifaximin on gut flora and staphyloccocus resistance, Dig Dis Sci, 58, 1676-1682, 2013.

41. Valentin T, Leitner E, Rohn A, Zollner-Schwetz I, Hoenigl M, Salzer HJF, Krause R: Rifaximin intake leads to emergence of rifampin-resistant staphyloccocci, JINF, 62, 34-38, 2011.

42. Idriss S, Foltys V, Tancin V, Kirchnerova K, Tancinova D, Zaujec K: Mastitis pathogens and their resistance againts antimicrobial agents in dairy cows in Nitra, Slovakisi, Slovak J Anim Sci, 47, 33-38, 2014. 


\title{
ISPITIVANJE ETIOLOGIJE SUBKLINIČKOG MASTITISA DŽERZEJ I HIBRID DŽERZEJ MLEČNIH KRAVA
}

\author{
GÜRLER Hande, FINDIK Arzu, GÜLTİKEN Nilgün, AY Serhan Serhat, ÇİFTÇİ \\ Alper, KOLDAŞ Ece, ARSLAN Serhat, FINDIK Murat
}

Cilj ove studije bio je ispitivanje etiologije subkliničkog mastitisa (SCM) mlečnih Jersey krava uz primenu bakterioloških i molekularnih metoda identifikacije. Tokom studije observirano je u Samsun oblasti u Turskoj 121 Jersey i 78 hibrid Jersey krava sa SCM. Ukupno 411 Kalifornija mastitis test (CMT) pozitivnih uzoraka mleka je bakteriološki ispitano. Prevalencija subkliničkog mastitisa bila je 54,75\% i 67,20\% kod Jersey i hibridnih krava. Tokom bakteriološkog ispitivanja ukupno 92 sojeva je izolovano iz 411 uzoraka mleka. Najčešće bakterije bile su Staphylococcus spp. (69,56\%). Među njima bili su Staphylococcus aureus (26.08\%), Streptococcus dysgalactiae (23.91\%), Enterococcus spp. (3.26\%) i Streptococcus agalactiae (3.26\%). Svi sojevi su identifikovani bakteriološkim metodama i PCRom. Gram negativne bakterije nisu izolovane. U zaključku, utvrđena je etiologija SCM kod čistokrvnih i hibridnih Jersey krava u Samsun oblasi kao i prevalencija bakterija. Relativno visoka učestalost SCM ukazuje na potencijanu potrebu razmatranja faktora koji doprinose razvoju mastitisa (npr. menadžment), kao i bakterijskih agenasa. Predstavljena studija, kao i druge studije, mogu doprineti razvoju vakcinalnih sojeva. 